\title{
THE EFFECT OF CALCIUM CHLORIDE AND CALCIUM LACTATE ON THE YIELDING OF Agaricus bisporus (LANGE) IMBACH
}

\author{
WPLYW CHLORKU WAPNIA \\ I MLECZANU WAPNIA NA PLONOWANIE PIECZARKI \\ Agaricus bisporus (LANGE) IMBACH
}

\begin{abstract}
The aim of the research was to assess the influence of calcium chloride and calcium lactate irrigation on the yield volume and dry matter content in two champignon strains, ie Amycel 2200 and Italspawn F59. When both strains were irrigated with calcium lactate, there was a significant decrease observed in the yield when the concentration of the solution was $0.6 \%$. On the other hand, when calcium chloride was applied to the Italspawn F59 strain, there was a significant decrease in the yield when the concentration was as low as $0.4 \%$, whereas the yield of the Amycel 2200 strain dropped when the concentration of calcium chloride was $0.6 \%$. The irrigation with calcium chloride and calcium lactate had influence on the content of dry matter in the champignon carpophores. When the solutions under investigation were applied at concentrations of 0.4 and $0.6 \%$, there was a significant increase observed in the content of dry matter in both strains.
\end{abstract}

Keywords: calcium chloride, calcium lactate, champignon, yield, dry matter

\section{Introduction}

Agaricus bisporus is the most popular edible mushroom in the world. Poland is the most important producer of this mushroom in the EU, followed by the Netherlands. As far as the conditions of cultivation are concerned, Agaricus bisporus has very high requirements. Producers continue their search for new methods, which should guarantee not only high yield but also the highest quality product. The fact that champignons turn brown after harvest is an important disadvantage to their quality. The irrigation of champignons with a chloride solution while growing is one of the methods preventing them from browning. Some authors $[1,2]$ found that irrigating champignons with $\mathrm{CaCl}_{2}$ while growing reduced postharvest browning. They found a positive correlation between the calcium concentration and colour.

\footnotetext{
${ }^{1}$ Department of Entomology and Environmental Protection, ${ }^{2}$ Department of Vegetable Crops, Poznań University of Life Sciences, ul. Dąbrowskiego 159, 60-594 Poznań, Poland, phone +48 618487966

* Corresponding author: sobieralski@up.poznan.pl
} 
The increased levels of calcium in mushrooms irrigated with $\mathrm{CaCl}_{2}$ may have decreased browning by increasing the vacuolar membrane integrity. Calcium chloride can also reduce the sensitivity of fruit bodies to mechanical injuries [3].

Researchers express different opinions about the influence of calcium chloride on the yield. According to some authors, the improvement in mushroom quality by calcium chloride irrigation is usually achieved at the expense of yield [4]. On the other hand, other authors reported that using calcium chloride during irrigation does not have significant effect on the yield [5].

Calcium preparations are also widely used to improve the post-harvest and storage quality of fruit and vegetables [6,7]. According to some authors [8], organic calcium salts, such as calcium lactate, are an alternative source of calcium. They prevent fruit from browning when the surface is cut [9] and enhance the nutritional value of foods [8]. There are numerous reports on the influence of calcium lactate on the yield of fruit and vegetables [10], but there is no information about the application of calcium lactate in mushroom production.

The aim of our study was to investigate the effect of calcium chloride and calcium lactate on the yield and dry matter content in Agaricus bisporus.

\section{Materials and methods}

Two champignon strains, ie Italspawn F59 and Amycel 2200 were used in the experiment. Both strains belong to the intermediate type (U2). Strains of this group form small, convex carpophores with smooth skin. They require substrate of high moisture, but are susceptible to early irrigation. Carpophores of the first flush are characterized by fast growth but worse quality [11].

The cultivation experiment was conducted on a phase II substrate from a composting facility. The cultivation was located in an air-conditioned chamber, in cases sized $38 \times 30 \times 18 \mathrm{~cm}$. The incubation was conducted at a temperature of $25^{\circ} \mathrm{C}$ for 12 days, where the relative humidity was $85-90 \%$. The substrate overgrown with mycelium was covered with a layer of high peat neutralised with calcium carbonate to a $\mathrm{pH}$ of 7.5. The covering layer was $5 \mathrm{~cm}$ thick. Carpophores were collected for 7 weeks and the yield was calculated per $1 \mathrm{~m}^{2}$ of the cultivated area.

The mushrooms were sprayed with calcium chloride and calcium lactate three times when the size of carpophores in each flush reached about $2 \mathrm{~cm} .400 \mathrm{~cm}^{3}$ of the solution was applied per $1 \mathrm{~m}^{2}$ of the substrate. Three concentrations of calcium chloride and calcium lactate were applied, ie $0.2 ; 0.4$ and $0.6 \%$.

The experiment was replicated four times, in two cultivation cycles.

\section{Results and discussion}

\section{The influence of calcium chloride and calcium lactate on the yield of two strains of Agaricus bisporus}

As the concentration of calcium chloride increased, the yield of both champignon strains decreased (Tables 1 and 2). When $\mathrm{CaCl}_{2}$ was applied to the Italspawn F59 strain, there was a significant decrease in the yield when the concentration was as low as $0.4 \%$, whereas the yield of the Amycel 2200 strain dropped when the concentration of calcium 
chloride was $0.6 \%$. When the highest concentration of calcium chloride was applied, ie $0.6 \%$, the yield of the Amycel 2200 strain dropped by $18.3 \%$, whereas the yield of the Italspawn F59 strain dropped by as much as $26.6 \%$ in comparison with the control. Desrumaux et al [12] also confirmed that the yield tended to decrease as the concentration of calcium chloride increased. According to Ulinski et al [13], there was a significant decrease in the yield only when calcium chloride was applied at a concentration of $0.45 \%$.

Table 1

Effect of calcium chloride on yielding of the Amycel 2200 strain

\begin{tabular}{|c|c|c|c|c|}
\hline \multirow{3}{*}{$\begin{array}{c}\text { Calcium chloride } \\
{[\%]}\end{array}$} & \multicolumn{4}{|c|}{ Yield $\left[\mathrm{kg} \cdot \mathrm{m}^{-2}\right]$} \\
\hline & \multicolumn{3}{|c|}{ Flush } & \multirow{2}{*}{ Total } \\
\hline & I & II & III & \\
\hline 0.0 & 10.3 & 7.9 & 3.6 & 21.8 \\
\hline 0.2 & 11.5 & 6.8 & 3.0 & 21.3 \\
\hline 0.4 & 12.5 & 5.8 & 2.1 & 20.4 \\
\hline 0.6 & 9.6 & 6.3 & 1.9 & 17.8 \\
\hline Mean & 11.0 & 6.7 & 2.7 & \\
\hline
\end{tabular}

$\mathrm{LSD}_{0.05}$ for yield - 2.1, $\mathrm{LSD}_{0.05}$ for flush - 1.8, $\mathrm{LSD}_{0.05}$ for interaction yield $\mathrm{x}$ flush - 3.6

Effect of calcium chloride on yielding of the Italspawn F59 strain

\begin{tabular}{|c|c|c|c|c|}
\hline \multirow{3}{*}{$\begin{array}{c}\text { Calcium chloride } \\
{[\%]}\end{array}$} & \multicolumn{4}{|c|}{ Yield $\left[\mathrm{kg} \cdot \mathrm{m}^{-2}\right]$} \\
\hline & \multicolumn{3}{|c|}{ Flush } & \multirow{2}{*}{ Total } \\
\hline & I & II & III & \\
\hline 0.0 & 11.2 & 6.8 & 4.2 & 22.2 \\
\hline 0.2 & 10.8 & 5.3 & 4.6 & 20.7 \\
\hline 0.4 & 9.3 & 7.9 & 2.6 & 19.8 \\
\hline 0.6 & 8.1 & 5.4 & 2.8 & 16.3 \\
\hline Mean & 9.9 & 6.4 & 3.6 & \\
\hline
\end{tabular}

$\mathrm{LSD}_{0.05}$ for yield - 1.9, $\mathrm{LSD}_{0.05}$ for flush - 1.5, $\mathrm{LSD}_{0.05}$ for interaction yield $\mathrm{x}$ flush - 3.8

According to Barden et al [14], a higher concentration (0.5\%) of $\mathrm{CaCl}_{2}$ decreased the yield and increased the quality and shelf-life. At a concentration of $0.5 \%$ the yield decreased by $16 \%$, but the solid content of harvested mushrooms increased by $16 \%$ and the shelf-life increased by about $64 \%$, mainly due to a decreased rate of postharvest bacterial growth and a concomitant reduction of surface browning.

Contrary to our results, Philippoussis et al [15] stated that the range of calcium chloride concentrations from 0.15 to $1 \%$ did not significantly affect the total yield and the yield produced during the third flush. According to those authors, calcium chloride concentrated at $0.55 \%$ favoured mushroom productivity in the first flush. In the second flush the lowest yield was obtained when $1 \%$ calcium chloride was used. According to Diamantopoulou et al [16], the application of calcium chloride concentrated at 0.10 and $0.15 \%$ resulted in an increase in the total yield, as compared with the control. On the other hand, when the concentrations of 0.20 and $0.25 \%$ were applied, the yield decreased.

Our research revealed significant differences in the mushroom yield volume between the flushes. The yield of the Amycel 2200 strain was $11 \mathrm{~kg} / \mathrm{m}^{2}$ in the first flush, whereas the yield of the Italspawn F59 strain amounted to about $10 \mathrm{~kg} / \mathrm{m}^{2}$. In the third flush the yield of the Italspawn F59 strain was nearly three times lower, whereas the yield of the Amycel 2200 
strain dropped nearly four times. Decreased yields in consecutive flushes were also confirmed by Beyer and Muthersbaugh [17], Koc et al [18], Ulinski et al [13].

When both champignon strains were irrigated with a calcium lactate solution while growing, there was a significant decrease in the yield observed when the concentration amounted to $0.6 \%$. There was a similar decrease in the yield of both strains, ie $14 \%$ in Amycel 2200 and $15.8 \%$ in Italspawn F59. The difference between the volume of the yield in the first and in the third flush exceeded four times for the Amycel 2200 strain, whereas for the Italspawn F59 strain it exceeded 2.5 times (Tables 3 and 4).

Effect of calcium lactate on yielding of the Amycel 2200 strain

Table 3

\begin{tabular}{|c|c|c|c|c|}
\hline \multirow{2}{*}{$\begin{array}{c}\text { Calcium lactate } \\
{[\%]}\end{array}$} & \multicolumn{3}{|c|}{ Ylush } & \multirow{2}{*}{ Total } \\
\cline { 2 - 5 } & I & II & III & 23.5 \\
\cline { 2 - 5 } & 11.5 & 8.3 & 3.7 & 22.9 \\
\hline 0.0 & 12.4 & 8.0 & 2.5 & 23.1 \\
\hline 0.2 & 11.8 & 9.3 & 2.0 & 20.2 \\
\hline 0.4 & 10.6 & 7.2 & 2.4 & \\
\hline 0.6 & 11.6 & 8.2 & 2.7 & $\mathbf{- 2}]$ \\
\hline Mean & &
\end{tabular}

$\mathrm{LSD}_{0.05}$ for yield - 2.3, $\mathrm{LSD}_{0.05}$ for flush - 1.8, $\mathrm{LSD}_{0.05}$ for interaction yield $\mathrm{x}$ flush -3.7

Effect of calcium lactate on yielding of the Italspawn F59 strain

Table 4

\begin{tabular}{|c|c|c|c|c|}
\hline \multirow{3}{*}{$\begin{array}{c}\text { Calcium lactate } \\
{[\%]}\end{array}$} & \multicolumn{4}{|c|}{ Yield $\left[\mathrm{kg} \cdot \mathrm{m}^{-2}\right]$} \\
\hline & \multicolumn{3}{|c|}{ Flush } & \multirow{2}{*}{ Total } \\
\hline & I & II & III & \\
\hline 0.0 & 10.1 & 7.4 & 4.0 & 21.5 \\
\hline 0.2 & 10.8 & 6.9 & 4.3 & 22.0 \\
\hline 0.4 & 9.6 & 8.7 & 3.5 & 21.8 \\
\hline 0.6 & 8.1 & 6.4 & 3.6 & 18.1 \\
\hline Mean & 9.7 & 7.4 & 3.9 & \\
\hline
\end{tabular}

$\mathrm{LSD}_{0.05}$ for yield - 1.9, $\mathrm{LSD}_{0.05}$ for flush - 2.0, $\mathrm{LSD}_{0.05}$ for interaction yield $\mathrm{x}$ flush - 2.6

\section{The influence of calcium chloride and calcium lactate on the content of dry matter in two strains of Agaricus bisporus}

According to Van Loon et al [19], the dry matter content is an important indicator of mushroom quality. According to those authors, the content of dry matter in the champignon carpophores increased as the concentration of the applied calcium chloride increased. Those findings are in agreement with our observations, where the application of calcium chloride and calcium lactate concentrated at 0.4 and $0.6 \%$ resulted in an increase in the content of dry matter in the carpophores of both strains under study (Tables 5-8).

Ulinski et al [13] also observed that when the concentration of calcium chloride increased, the content of dry matter in the champignon carpophores was higher in the second and third flush. However, the authors did not observe significant influence of calcium chloride on the content of dry matter in the first flush.

Our experiment revealed that both strains differed in the content of dry matter between the first and third flush when calcium lactate was applied. When calcium chloride was applied, the Amycel 2200 strain revealed a difference in the content of dry matter between 
the first and third flush. When calcium chloride was applied to the Italspawn F59 strain, there was a significant difference in the content of dry matter between all the flushes.

Table 5

Effect of calcium chloride on the dry matter content of Amycel 2200 strain

\begin{tabular}{|c|c|c|c|c|}
\hline \multirow{2}{*}{$\begin{array}{c}\text { Calcium chloride } \\
{[\%]}\end{array}$} & \multicolumn{4}{|c|}{ Dry matter content [\%] } \\
\cline { 2 - 5 } & I & II & III & \multirow{2}{*}{ Mean } \\
\cline { 2 - 5 } & 7.2 & 7.4 & 7.5 & 7.4 \\
\hline 0.0 & 7.2 & 7.6 & 7.6 & 7.5 \\
\hline 0.2 & 7.7 & 7.7 & 7.9 & 7.8 \\
\hline 0.4 & 7.6 & 7.8 & 7.8 & 7.7 \\
\hline 0.6 & 7.4 & 7.6 & 7.7 & \\
\hline Mean & &
\end{tabular}

$\mathrm{LSD}_{0.05}$ for concentration - $0.3, \mathrm{LSD}_{0.05}$ for flush - $0.3, \mathrm{LSD}_{0.05}$ for interaction concentration $\mathrm{x}$ flush - 0.5

Effect of calcium chloride on the dry matter content of Italspawn F59 strain

Table 6

\begin{tabular}{|c|c|c|c|c|}
\hline \multirow{3}{*}{$\begin{array}{c}\text { Calcium chloride } \\
{[\%]}\end{array}$} & \multicolumn{4}{|c|}{ Dry matter content [\%] } \\
\hline & \multicolumn{3}{|c|}{ Flush } & \multirow{2}{*}{ Mean } \\
\hline & I & II & III & \\
\hline 0.0 & 7.0 & 7.2 & 7.4 & 7.2 \\
\hline 0.2 & 7.1 & 7.3 & 7.3 & 7.2 \\
\hline 0.4 & 7.4 & 7.6 & 7.8 & 7.6 \\
\hline 0.6 & 7.3 & 7.7 & 7.8 & 7.6 \\
\hline Mean & 7.2 & 7.5 & 7.6 & \\
\hline
\end{tabular}

$\mathrm{LSD}_{0.05}$ for concentration - $0.4, \mathrm{LSD}_{0.05}$ for flush - $0.3, \mathrm{LSD}_{0.05}$ for interaction concentration $\mathrm{x}$ flush - 0.5

Table 7

Effect of calcium lactate on the dry matter content of Amycel 2200 strain

\begin{tabular}{|c|c|c|c|c|}
\hline \multirow{3}{*}{$\begin{array}{c}\text { Calcium lactate } \\
{[\%]}\end{array}$} & \multicolumn{4}{|c|}{ Yield $\left[\mathrm{kg} \cdot \mathrm{m}^{-2}\right]$} \\
\hline & \multicolumn{3}{|c|}{ Flush } & \multirow{2}{*}{ Mean } \\
\hline & I & II & III & \\
\hline 0.0 & 7.3 & 7.5 & 7.6 & 7.5 \\
\hline 0.2 & 7.4 & 7.3 & 7.5 & 7.2 \\
\hline 0.4 & 7.6 & 7.8 & 7.9 & 7.4 \\
\hline 0.6 & 7.6 & 7.9 & 7.8 & 7.8 \\
\hline Mean & 7.5 & 7.6 & 7.7 & \\
\hline
\end{tabular}

$\mathrm{LSD}_{0.05}$ for concentration - $0.3, \mathrm{LSD}_{0.05}$ for flush - $0.2, \mathrm{LSD}_{0.05}$ for interaction concentration $\mathrm{x}$ flush - 0.4

Table 8

Effect of calcium lactate on the dry matter content of Italspawn F59 strain

\begin{tabular}{|c|c|c|c|c|}
\hline \multirow{3}{*}{$\begin{array}{c}\text { Calcium lactate } \\
{[\%]}\end{array}$} & \multicolumn{4}{|c|}{ Yield $\left[\mathrm{kg} \cdot \mathrm{m}^{-2}\right]$} \\
\hline & \multicolumn{3}{|c|}{ Flush } & \multirow{2}{*}{ Mean } \\
\hline & $\mathbf{I}$ & II & III & \\
\hline 0 & 7.1 & 7.1 & 7.3 & 7.2 \\
\hline 0.2 & 7.3 & 7.3 & 7.5 & 7.4 \\
\hline 0.4 & 7.4 & 7.6 & 7.6 & 7.5 \\
\hline 0.6 & 7.5 & 7.4 & 7.6 & 7.5 \\
\hline Mean & 7.3 & 7.4 & 7.5 & \\
\hline
\end{tabular}

$\mathrm{LSD}_{0.05}$ for concentration - $0.3, \mathrm{LSD}_{0.05}$ for flush - $0.2, \mathrm{LSD}_{0.05}$ for interaction concentration $\mathrm{x}$ flush - 0.5 


\section{Conclusions}

1. The yield of both Agaricus strains decreased as the concentration of calcium chloride and calcium lactate increased.

2. Significant decrease in yield of both strains was observed when calcium chloride and calcium lactate were applied at concentration of $0.6 \%$. Additionally, significant decrease of yield was obtained after application of calcium chloride at concentration of $0.4 \%$ in the Italspawn F59 strain.

3. The application of calcium chloride at concentration of $0.6 \%$ resulted in a greater reduction in the yield of both strains than irrigation with calcium lactate at the same concentration.

4. The volume of the yield decreased in consecutive flushes both in the Amycel 2200 and Italspawn F59 strains.

5. The content of dry matter increased in both strains when calcium chloride and calcium lactate concentrated at 0.4 and $0.6 \%$ were applied to the champignons.

\section{References}

[1] Miklus $\mathrm{MB}$, Beelman $\mathrm{RB}$. $\mathrm{CaCl}_{2}$ treated irrigation water applied to mushroom crops (Agaricus bisporus) increases Ca concentration and improves postharvest quality and shelf life. Mycologia. 1996;88:403-409.

[2] Beelman RB, Simons S. Addition of calcium chloride to irrigation water increases calcium content and improves quality of Agaricus mushrooms independent of inherent calcium content. In: Van Griensven LJLD, editor. Science and Cultivation of Edible Fungi. Rotterdam: Balkema; 2000:491-497.

[3] Kukura JL, Beelman RB, Peiffer MW. Calcium chloride addend to irrigation water of mushrooms (Agaricus bisporus) reduces postharvest browning. J Food Sci. 1998;63:454-457. DOI: 10.1111/j.1365-2621.1998.tb15763.x.

[4] Solomon JM, Beelman RB, Bartly CE. Addition of calcium chloride and stabilized chloride dioxide to irrigation water to improve quality and shelf-life of Agaricus bisporus. Mushroom Sci. 1991;13:695-701.

[5] Diamantopoulou P, Philippoussis A, Lahouvaris L, Parissopoulos G. The effect of calcium chloride irrigation on yield and quality of Agaricus bisporus. Mushroom Sci. 2000;15:475-489.

[6] Izumi H, Watada AE. Calcium treatments affects storage quality of shredded carrots. J Food Sci. 1994;59:106-109.

[7] Luna-Guzman I, Garrett DM. Comparison of calcium chloride and calcium lactate effectiveness in maintaining shelf stability and quality of fresh-cut cantaloupes. Post Biol Tech. 2000;19:61-72. DOI: org/10.1016/S0925-5214(00)00079-X.

[8] Alandes L, Hernando I, Quilles A, Pérez-Munuera I, Lluch MA. Cell wall stability of fresh-cut Fuji Apple treated with calcium lactate. J Food Sci. 2006;71:615-620. DOI: 10.1111/j.1750-3841.2006.00180.x.

[9] Manganaris GA, Vasilakakis M, Diamantidis G, Mingani I. Effect of calcium additives on physicochemical aspects of cell wall pectin and sensory attributes of canned peach (Prunus persica (L.) Batsch cv. Andross). J Sci Food Agric. 2005;85(10):1773-1778. DOI: 10.1002/jsfa.2182.

[10] Manganaris GA, Vasilakakis M, Diamantidis G, Mingani I. The effect of postharvest calcium application on tissue calcium concentration, quality attributes, incidence of flesh browning and cell wall physicochemical aspects of peach fruits. Food Chem. 2007;100:1385-1392. DOI: org/10.1016/j.foodchem.2005.11.036.

[11] Sakson N. Pieczarka - uprawa intensywna. Poznań: PWRiL; 2013:49.

[12] Desrumaux B, Calus A, Sedeyn P. Water hardness and $\mathrm{CaCl}_{2}$ in Dutch mushroom growing systems: effect on field and quality. Science and cultivation of edible fungi. 15th International Congress on the Science and Cultivation of Edible Fungi. Maastricht. Netherlands. May 15-19, 2000:467-474.

[13] Uliński Z, Szudyga K, Dyki B. Effect of calcium chloride addition to irrigation water on yield and quality of Agaricus bisporus and microscopic structure of surface cell layer of fruit bodies. Veg Crops Res Bull. 2005;63:150-160.

[14] Barden CL, Beelman RB, Bartley CE, Schisler LC. The effect of calcium chloride added to the irrigation water in quality and shelf-life of harvested mushrooms. J Food Protect. 1990;53(9):759-762. 
[15] Philippoussis A, Diamantopolou P, Zervakis G. Calcium chloride irrigation influence in yield, calcium content, quality and shelf-life of the white mushroom Agaricus bisporus. J Sci Food Agric. 2001;81:1447-1454. DOI: 10.1002/jsfa.968.

[16] Diamantopoulou P, Philippoussis A. Production attributes of Agaricus bisporus white and off-white strains and the effect of calcium chloride irrigation on productivity and quality. Scientia Hort. 2001;91:379-391. DOI: org/1016/S0304-4238(01)00274-6.

[17] Beyer DM, Muthersbaugh H. Nutrient supplements that influence later break yield of Agaricus bisporus. Can J Plant Sci. 1996;76:835-840.

[18] Koc G, Rak J, Gąsiorowska B, Radzka E, Jankowska J. Hydrożele w uprawie pieczarki dwuzarodnikowej. Infrastruktura i Ekologia Terenów Wiejskich. 2011;6:195-204.

[19] Van Loon PCC, Swinkels HATI, Van Griensven LJLD. Dry matter content in mushrooms (Agaricus bisporus) as an indicator for mushroom quality. In: Van Griensven, editor. Science and Cultivation of Edible Fungi. Rotterdam: Balkema; 2000:507-509.

\title{
WPLYW CHLORKU WAPNIA I MLECZANU WAPNIA NA PLONOWANIE PIECZARKI Agaricus bisporus (LANGE) IMBACH
}

\author{
${ }^{1}$ Katedra Entomologii i Ochrony Środowiska, ${ }^{2}$ Katedra Warzywnictwa
}

Uniwersytet Przyrodniczy w Poznaniu

\begin{abstract}
Abstrakt: Celem badań była ocena wpływu podlewania uprawy chlorkiem wapnia i mleczanem wapnia na wielkość plonu oraz zawartość suchej masy u dwóch odmian pieczarki, tj. Amycel 2200 i Italspawn F59. W przypadku podlewania obu odmian mleczanem wapnia stwierdzono istotny spadek plonu, gdy stężenie zastosowanego roztworu wynosiło $0,6 \%$. Natomiast istotny spadek plonu przy zastosowaniu chlorku wapnia u odmiany Italspawn F59 nastąpił już przy stężeniu 0,4\%, a u odmiany Amycel 2200, gdy chlorek wapnia zastosowano w stężeniu 0,6\%. Podlewanie chlorkiem i mleczanem wapnia miało wpływ na zawartość suchej masy w owocnikach pieczarki. Stwierdzono znaczący wzrost zawartości suchej masy u obu odmian, gdy badane roztwory zastosowano w stężeniu 0,4 i $0,6 \%$.
\end{abstract}

Słowa kluczowe: chlorek wapnia, mleczan wapnia, pieczarka, plon, sucha masa 